\title{
Evaluation of thyroid disorders in abnormal uterine bleeding
}

\section{Bharat Kumar Bilwal, Apurva Garg*}

Department of Obstetrics and Gynecology, RNT Medical College, Udaipur, Rajasthan, India

Received: 25 April 2019

Accepted: 03 May 2019

\section{*Correspondence:}

Dr. Apurva Garg,

E-mail: apurvagarg89@gmail.com

Copyright: ( $\odot$ the author(s), publisher and licensee Medip Academy. This is an open-access article distributed under the terms of the Creative Commons Attribution Non-Commercial License, which permits unrestricted non-commercial use, distribution, and reproduction in any medium, provided the original work is properly cited.

\section{ABSTRACT}

Background: Abnormal uterine bleeding (AUB) is a common clinical presentation in gynecology. Alteration in thyroid hormones level has been associated with menstrual disturbances. This study is aimed to know the prevalence of thyroid disorders amongst AUB patients and also the different patterns of menstrual abnormalities associated with thyroid disorders.

Methods: 100 Patient of clinically diagnosed AUB were taken from gynecology OPD at RNT Medical College Udaipur from October 2019 to March 2019. All the patients from 19 to 45 age groups presenting with menstrual disturbances were tested for thyroid function by measuring ST3, ST4, and S.TSH. Statistical analysis done by percentage formula.

Results: Out of 100 women of AUB, majority were in the age group of 31-40 years (38\%). 44\% presented with menorrhagia. $65 \%$ were euthyroid, $17 \%$ had subclinical hypothyroidism, $15 \%$ had overt hypothyroidism and $3 \%$ were diagnosed as hyperthyroid. Subclinical hypothyroidism, overt hypothyroidism and hyperthyroidism were detected mostly in the age group of 31-40 years. The commonest bleeding abnormalities in hypothyroid patient were oligomenorrhoea while most of the hyperthyroid cases were having menorrhagia.

Conclusions: The study concludes that biochemical evaluation of thyroid function is an easy, reliable method and should be made mandatory in all cases of AUB.

Keywords: Abnormal uterine bleeding, Euthyroid, Hypothyroid, Hyperthyroid, Thyroid disorders

\section{INTRODUCTION}

Abnormal uterine bleeding is a common complaint encountered in Gynaecology OPD. It occurs in $9-14 \%$ of women from Menarche to Menopause affecting quality of life imposing financial burden. ${ }^{1}$ Thyroid dysfunction causes broad spectrum of reproductive disorders from abnormal sexual development, menstrual irregularities, infertility and premature menopause. ${ }^{2}$ Thyroid disorders are 10 times more common in women and increase prevalence of thyroid disorders in women is possibly due to auto immune nature. ${ }^{3}$ Menstrual disturbances accompany clinical alterations in thyroid function and every clinician must have encountered altered menstrual pattern among women suffering from hypo or hyper thyroidism. Diseases of thyroid gland are among the most prevalent disorders worldwide second only to diabetes. ${ }^{4}$

\section{Term used to describe AUB3}

- $\quad$ Oligomenorrhoea: bleeding occurs at interval of $>35$ days

- Polymenorrhoea: bleeding occurs at interval of $<21$ days

- Menorrhagia: bleeding occurs at normal interval but with a heavy flow ( $\geq 80 \mathrm{ml}$ ) or duration of $>7$ days 
- Meno- metrorrhagia: bleeding occurs at irregular/ non-cyclic interval with heavy flow $(\geq 80 \mathrm{ml})$ or duration of $>7$ days

- Metrorrhagia: irregular bleeding that occurs between ovulatory cycles inter-menstrual bleeding.

Objective of this study is to evaluate thyroid disorder in patients with Abnormal Uterine Bleeding in reproductive age group from 15 to 45 years which will help in further management.

\section{METHODS}

It is a cross-sectional, prospective observational study, conducted on 100 women coming to Out-patient department with complaint of AUB.

From October 2019 to March 2019, study conducted at Obstetrics and Gynecology department, RNT Medical College, Udaipur, Rajasthan, India.

\section{Inclusion criteria}

- Females in age group of 15-45 years with complaint of abnormal uterine bleeding.

\section{Exclusion criteria}

- Known cases of thyroid disease, hyperprolactinemia and coagulopathy and also the patients on anticoagulant drugs.

A detailed history of all the patients included in the study was taken. The detailed gynaecological history and also the detailed present and past menstrual history were taken from the patients. A detailed examination including general and gynaecological examination was done by which the obvious pelvic pathologies were ruled out. All patients were advised for routine investigations like CBC, Blood sugar, Urine routine and BT, CT and thyroid profile which included T3, T4 and TSH. Ultrasound of the pelvis was also done to rule out any pelvic pathology as the cause of menstrual irregularities.

After the reports of thyroid, the patients were diagnosed as euthyroids, subclinical hypothyroids, hypothyroids and hyperthyroids. Data were collected and mentioned in percentages. Stastical analysis done by percentage method.

\section{RESULTS}

The maximum number of patients of AUB in our study were of 31-40 years of age (38\%), followed by 21-30 years of age $(31 \%)$. Above 40 years patients are $10 \%$. No of patients less than 20 years of age is $21 \%$. Maximum no if patient in age group 31-40 years because of maximum OPD occurs in this age group (Table 1).
Table 1: Age wise distribution of AUB cases.

\begin{tabular}{|lll|}
\hline Age groups & No. of patients & Percentage \\
\hline$<20$ & 21 & 21 \\
\hline $21-30$ & 31 & 31 \\
\hline $31-40$ & 38 & 38 \\
\hline$>40$ & 10 & 10 \\
\hline
\end{tabular}

Table 2: Parity of AUB patients.

\begin{tabular}{|lll|}
\hline Parity & No. of patients & Percentage \\
\hline Unmarried & 20 & 20 \\
\hline Nullipara & 6 & 6 \\
\hline Primipara & 20 & 20 \\
\hline Para 2 & 34 & 34 \\
\hline$\geq$ Para 3 & 20 & 20 \\
\hline
\end{tabular}

The mean age was 29.5 years. Majority of patients were multiparous with parity two (34\%), while $20 \%$ were unmarried, patient with parity 3 are $20 \%$ and $6 \%$ nulliparous (Table 2).

Table 3: Bleeding pattern in AUB patients,

\begin{tabular}{|lll|}
\hline Bleeding pattern & No. of patients & Percentage \\
\hline Menorrhagia & 44 & 44 \\
\hline Metrorrhagia & 10 & 10 \\
\hline Meno- Metrorrhagia & 10 & 10 \\
\hline Polymenorrhoea & 16 & 16 \\
\hline Oligomenorrhoea & 20 & 20 \\
\hline
\end{tabular}

The major menstrual complaint of AUB patients was menorrhagia (44\%), $20 \%$ presented with oligomernorrhoea, $16 \%$ had polymenorrhoea, $10 \%$ have meno-metrorrhagia maximum patients were of menorrhagia (Table 3).

The $65 \%$ of the patients with AUB were euthyroid, 24\% had hypothyroidism and $09 \%$ were diagnosed to be subclinical hypothyroid. $2 \%$ patients had hyperthyroidism.

Hypothyroidism is mainly present with AUB (Table 4). Cause of AUB in euthyroid patient is others like endometrial causes, polyp, cervicitis, PID. Maximum cases were found of hypothyroidism.

In present study, among 65 cases of Euhyroid 44 (81\%) patient have menorrhagia, 20 (30\%) have oligomenorrhoea, 16 (24\%) have polymenorrhoea. patients with hypothyroidism presented mainly with oligomenorrhoea ( 8 out of 24 patients i.e.33.3\%), menorrhagia present in 5 cases $(20 \%), 7$ cases have metrorrhagia (29\%). Patients who were hyperthyroid presented with menorrhagia (50\%) and 50\% cases show polymenorrhoea (Table 5). 
Table 4: Thyroid dysfunction in AUB patients.

\begin{tabular}{|lllll|} 
& Euthyroid & Hypothyroid & Sub. hypothyroid & hyperthyroidism \\
\hline No. of patients & 65 & 24 & 9 & 2 \\
\hline
\end{tabular}

Table 5: Distribution of different AUB pattern in relation to thyroid dysfunction.

\begin{tabular}{|llllll|}
\hline Bleeding pattern & No. of patients & Euthyroid & Hypothyroid & Subclinical hypothyroid & hyperthyroid \\
\hline Menorrhagia & 44 & 36 & 5 & 2 & 1 \\
\hline Polymenorrhoea & 16 & 11 & 3 & 1 & 1 \\
\hline Metro rrhagia & 10 & 2 & 7 & 1 & \\
\hline Meno-metrorrhagia & 10 & 9 & 1 & 5 \\
\hline Oligomenorrhoea & 20 & 7 & 8 & & \\
\hline
\end{tabular}

\section{DISCUSSION}

The majority of patients of AUB (38\%) were in the age group of 31-40 years in our study. Pilli et al had 58\% cases in age group of 21-30 years. ${ }^{5}$ Jinger SK et al, in their study of 100 women with AUB had $49 \%$ in $20-30$ years age group. ${ }^{6}$

Pilli et al, reported that AUB is seen in $87 \%$ multipara, $7 \%$ primipara and $6 \%$ nulliparous..$^{5}$ In present study also majority of patients were Para $2(20 \%)$. Menorrhagia is the main complaint in the patients of abnormal uterine bleeding (44\%) which was also seen in the studies by Pilli et al in $34 \%$, in the study by Pahwa $\mathrm{S}$ et al study it was in $50 \%$ patients and in Deshmukh et al study $40 \%$ had menorrhagia. ${ }^{5,7,8}$

Oligomenorrhoea is the next common menstrual disorder followed by polymenorrhoea and metrorrhagia.

The 35 patients out of 100 patients, showed thyroid dysfunction (35\%). In the study of Pahwa S et al $24 \%$ had thyroid dysfunction. ${ }^{7}$ In the study by Marimuthu K et al, out of 250 cases of AUB, 68 (27.2\%)cases had thyroid dysfunction. ${ }^{9}$ Jinger SK et al found $47 \%$ patients having thyroid dysfunction in their study and $53 \%$ euthyroid. ${ }^{6}$

The main thyroid dysfunction noted was hypothyroidism including subclinical $(9 \%)$ and overt hypothyroidism $(24 \%)$ in our study. Similarly, in the study by Marimuthu $\mathrm{K}$ et al $15.6 \%$ were hypothyroid, $3.2 \%$ had subclinical hypothyroidism and $7.2 \%$ were hyperthyroid. ${ }^{9}$ Pahwa $\mathrm{S}$ et al observed in their study that $22 \%$ of cases were found to be hypothyroid, 2\% hyperthyroid and $76 \%$ were euthyroid.

Sampath $S$ et al had done their study on clinicbiochemical spectrum of hypothyroidism and found a mean age of 36.2 years among 944 women referred for thyroid testing. In this study, they found that the mean age of females with subclinical hypothyroidism was 5.4 years less than those with overt hypothyroidism. ${ }^{10}$
The $65 \%$ of cases of hypothyroid (both subclinical and overt) in our study, were exhibiting oligomenorrhoea. The similar results were seen in $57.13 \%$ patients in the study by Nair RV et al and in $46.15 \%$ patients in the study by Bharucha $\mathrm{M}$ et al. ${ }^{11,12}$

The main symptom in patients diagnosed to have hyperthyroidism was menorrhagia $(50 \%)$ in our study which was comparable to $63.6 \%$ patients in the study by Singh L et al. ${ }^{13}$

\section{CONCLUSION}

With the advent of modern hormonal assay techniques, precise estimation of thyroid hormone in serum is possible in a rapid and reliable manner. Hence investigating a patient with AUB, evaluation of thyroid function forms an essential component. AUB patients in the age group of 31-40 years mostly suffered from thyroid disorders and thus must be evaluated for it. This can avoid unnecessary hormonal treatment and surgical intervention.

Funding: No funding sources

Conflict of interest: None declared

Ethical approval: The study was approved by the Institutional Ethics Committee

\section{REFERENCES}

1. Hoffman B, Schorge J, Schaffer J, Halvorson L, Bradshaw K, Cunningham F. Abnormal uterine bleeding Williams Gynecology. $2^{\text {nd }}$ ed. McGrawHill; 2012:220-234.

2. Dutta DC. Abnormal menstrual bleeding. Textbook of Gynaecology including contraception. $4^{\text {th }}$ ed. New Central Book Agency(P) Ltd.; 2005:177.

3. Speroff L, Glass LH, Kass NG. Clinical gynecological endocrinology and infertility, $6^{\text {th }}$ edn. Baltimore. Lippincott Williams ac Wilkins; 1999:201-238:575-9. 
4. Khan RL. Gynaecology: formerly known as by; Five Teachers Gynaecology, $3^{\text {rd }}$ ed. CBS Publishers and Distributors Pvt. Ltd. 2009:255.

5. Pilli GS, Sethi B, Dhaded AV, Mathur PR, Dysfunctional uterine bleeding. J Obstet Gynae India. 2001;52(3):87-9.

6. Jinger SK, Verma A, Dayma I, Talreja T. To study the thyroid profile in menstrual disorder at tertiary care hospital in northern western Rajasthan, India. Int J Res Med Sci. 2017;5(5):2212-4.

7. Pahwa S, Gupta S, Kumar J. Thyroid dysfunction in dysfunctional uterine bleeding. J Adv Res Bio Sci. 2013;5(1):78-3.

8. Deshmukh PV, Boricha BG, Pandey A. The association of thyroid disorders with abnormal uterine bleeding. Int $\mathrm{J}$ Reprod Contracep Obstet Gynecol. 2015;4(3):701-8.

9. Marimuthu K, Loganathan M. Influence of thyroid gland in women with abnormal uterine bleeding in reproductive age group. Int $\mathbf{J}$ Reprod Contracep Obstet Gynecol. 2017;6(6):2222-5.

10. Sampath S, Singh P, Somani BL, Arora MM, Batra HS. Study of clinicobiochemical spectrum of hypothyroidism. MJAFI. 2017;63(3):233-6.

11. Nair RV. Evaluation of thyroid profile in patients with abnormal uterine bleeding. Int J Health Sci Res. 2015;15(9):94-8.

12. Menon UK, Barucha KE. Menstrual dysfunction and thyroid diseases. J Obst Gynal India. 1995;45(4):521-6.

13. Singh L, Agarwal CG, Chowdhary SR, Mehra P, Khare R. Thyroid profile in infertile women. J Obstet Gynecol India. 1990;40:248.

Cite this article as: Bilwal BK, Garg A. Evaluation of thyroid disorders in abnormal uterine bleeding. Int J Reprod Contracept Obstet Gynecol 2019;8:2236-9. 